\title{
運動する心臓表面での右冠状動脈の計算流体力学シミュレーション
}

\section{Computational fluid dynamics simulation of the right coronary artery on a beating heart}

\author{
○学 林 弘之 (名工大院)，山口隆美 （名工大）
}

Hiroyuki HAYASHI, Dept. Mech. and Sys. Eng., Nagoya Institute of Technology, Gokiso-cho, Showa-ku, Nagoya 466-8555 Takami YAMAGUCHI, Dept. Mech. and Sys. Eng., Nagoya Institute of Technology, Gokiso-cho, Showa-ku, Nagoya 466$8555 \quad$ Key Words: Coronary plaque, Right coronary artery, Ordinary helix, CFD, WSS

\section{1. 目的}

本研究では, 心臟の収縮・拡張に伴って変形する右冠状 動脈を模擬した計算モデルを用いて数值流体力学（CFD） シミュレーションを行い，その結果，特に壁面せん断応力 分布の結果から，䋆腫生成の局在性との関連性を考察する ことを目的とした.

\section{2. 方法}

計算モデルは，心臓を円柱で近似し，その円柱表面に巻 き付く常らせんを中心線とするねじり管であると近似した。 Fig.1に計算モデルと右冠状動脈の造影所見を対比して示す. 体積の時間変化は，一次近似として余弦関数で定義し，体 積変化率は $75 \%$ （すなわち駆出率=0.75）とした。壁の運動 と流体の運動の結合には，以前報告されている方法に基づ き，壁の運動は流れの発達に対して，準定常であると仮定 した.
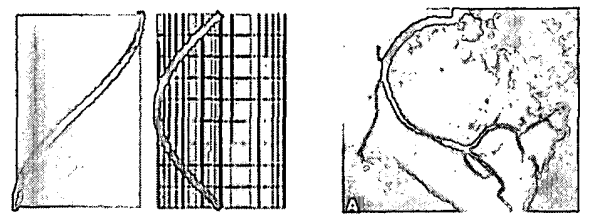

Fig.1 CFD model and angiogram of the right coronary artery

また, 右冠状動脈の曲率と㨭率の時間的変化が内部の流 れに影響を及ぼすかどうか調べるため，Fig.2 に示す，異な る変形様式を持つ 3 つの計算モデルを用意した。Fig.2(a)に 示す計算モデルは，心臓を模擬した円柱が相似変形すなわ ち, 体積変化の間, 直径及び高さそれそれの変化割合が等 しく保たれたまま変形した場合の計算モデルである.Fig.2(b) は円柱が高さ方向のみ変形した場合, Fig.2(c)は半径方向の み変形した場合の計算モデルである。

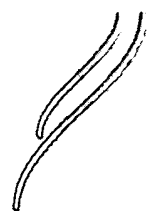

(a)

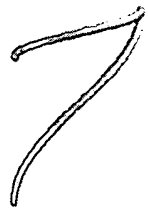

(b)

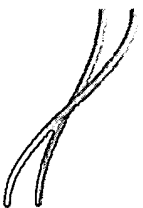

(c)
Fig.2 The shapes of the CFD model of the right coronary artery at early diastole and early systole.

支配方程式は，非圧縮ニュートン流体におけるナビェ・ ストークスの方程式，物性値は水の值を用いた。境界条件 は，壁面において no-slip 条件，出口において 0 圧力，0 速 度勾配であり，流入条件として，入口において断面垂直方 向に一様定常流を与えた。レイノルズ数は，入口断面の管 直径を代表長さとし，流入速度から定義される $\mathrm{Re}=100$ とし
た。 1 心周期を 1 秒（すなわち，心拍数 60/分）とした. 計 算コードには, Software CRADLE 社製の SCRYU ver.1.9 を 用いた。可視化には，ヴァイナス社製の FIELDVIEW ver7 を用いた。

\section{3. 結果}

円柱の高さ方向及び半径方向に変形するモデルを用いた 場合，Fig.3 (b),(c)に示すように，モデルの変形に伴って壁 面せん断応力分布が変化することが確認できた。また，全 てのモデルにおいて，壁面せん断応力は常に外側壁におい て高い值を示し，内側壁において低い值を示すことが認め られた。

円柱が高さ方向及び半径方向のみ変形する場合, モデル の変形に伴って, Fig.4 (b),(c)に示される上下の渦が断面に 対して回転したり，形を変えながら，流れの様子を大きく 変化させることが認められた。

これらの結果から，モデルの変形に伴う壁面せん断応力 や流線の変化の様子は, 曲率が大きく変化する場合におい て，大きく変化するのではないかと考えられた。

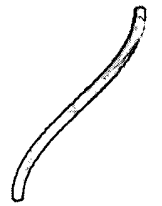

(a)

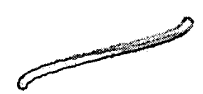

(b)

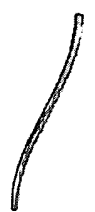

(c)
Fig. 3 WSS distribution pattern at early systole.

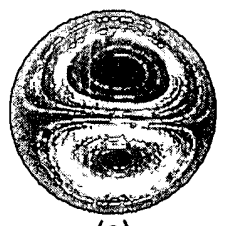

(a)

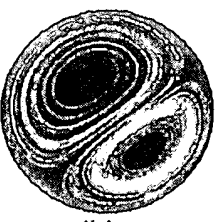

(b)

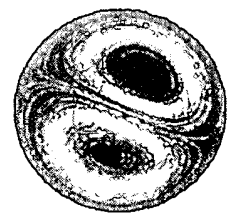

(c)
Fig. 4 Streamline patterns in cross sections of the middle of the right coronary artery models

\section{4.考察および結果}

本研究では, 流入条件に一様定常流を用いたが，計算結 果から, いくつか興味深い流体力学量の変化が観察できた. このことから，粥腫の生成及び破綻のメカニズムを解明す るうえで, 非定常の流入条件と，心臓の運動に伴うモデル の変形を考えることが重要であると予想できた。

今後，実際の右冠状動脈を模擬したモデルを開発すると 同時に，現在の単純化された計算モデルによっても，内部 での特徵ある流れの様子や，重要な力学的作用の解析には 有用であるので，より詳しいパラメトリックな計算を実施 する。 